Journal of Southeast Asian

\title{
Review of Chath pierSath's On Earth Beneath Sky, Loom Press, 2020
}

George Chigas

University of Massachusetts Lowell, george_chigas@uml.edu

Follow this and additional works at: https://docs.lib.purdue.edu/jsaaea

Part of the American Literature Commons, Literature in English, North America, Ethnic and Cultural Minority Commons, Poetry Commons, and the South and Southeast Asian Languages and Societies Commons

\section{Recommended Citation}

Chigas, George (2021) "Review of Chath pierSath's On Earth Beneath Sky, Loom Press, 2020," Journal of Southeast Asian American Education and Advancement. Vol. 16 : Iss. 1, Article 13.

DOI: $10.7771 / 2153-8999.1222$

Available at: https://docs.lib.purdue.edu/jsaaea/vol16/iss1/13

This document has been made available through Purdue e-Pubs, a service of the Purdue University Libraries. Please contact epubs@purdue.edu for additional information.

This is an Open Access journal. This means that it uses a funding model that does not charge readers or their institutions for access. Readers may freely read, download, copy, distribute, print, search, or link to the full texts of articles. This journal is covered under the CC BY-NC-ND license. 


\title{
ISAAEA Journal of Southeast Asían American Education and Advancement
}

Vol. 16 Iss. $1(2021)$

WWW.JSAAEA.org

Book Review: pierSath, C. (2020). On Earth Beneath Sky. Loom Press. 143 pp. ISBN: 9781735168920

\author{
Reviewed by \\ George Chigas \\ University of Massachusetts Lowell
}

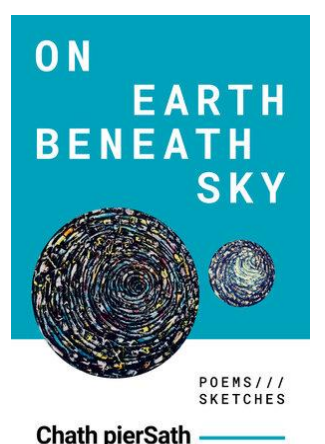

In the aftermath of genocide, survivors must often undergo a lifelong process of healing in an attempt to make sense of the traumatic events that ruptured their lives. They strive to come to a new understanding of themselves and the world and restore their trust in others. They attempt to regain a sense of selfworth and empowerment necessary for a healthy and meaningful existence. Each survivor's journey is unique, and some are able to go further than others. Those equipped to brave the dangers and difficulties of returning to the traumatic memories of the past and record their journey in words or images are rare and precious. Chath pierSath is one of those rare and precious survivors. His latest collection of poems and sketches, On Earth Beneath Sky, attests to the gains he has made along this difficult path, as well as the ongoing struggles with which he must still contend. While the traumatic legacy of the genocide may always haunt and cling to him like a shadow, the gains he has made in his journey toward healing mean it is no longer able to overpower him as it once did as he strives to reinvent himself and rediscover the world around him.

The careful organization of the 68 poems and sketches that comprise On Earth Beneath Sky purposefully chart Chath's journey up to this point. Rather than follow a chronological sequence that might erroneously infer "closure" or "moving on," the poems are divided into five sections that articulate an ongoing tug-of-war between self-discovery and alienation, loneliness and love. The five sections are bracketed by two poems that refer to Chath's mother, whose spirit is both at the center and periphery of the collection. The first poem, entitled "My Mother Wanted My Brother to Take Me Back to Her," records Chath's escape from Cambodia in 1980 with his older brother and sister, and his permanent separation from his mother, who died two years later in Cambodia, when Chath, 14 years old, was living in Denver, Colorado. The final poem, "The Way I Want to Remember My Cambodia," marks Chath's current place in his journey toward healing. The poem tells us firstly, that Chath is making progress in his attempt to integrate the traumatic events of the genocide into his understand of himself and the world and secondly, that he is ready to embark on the next phase his journey as a Cambodian American poet and artist. The final poem of the collection invokes the memory of his mother's cooking fire, "I recall my mother's cooking fire, her salted-fish grilled on burning charcoal," and ends with the lines:

\section{(a)}

SORERIGHISRESERVEDReaders are free to copy, display, and distribute this article, as long as the work is attributed to the author(s) and the Journal of Southeast Asian American Education \& Advancement, it is distributed for non-commercial purposes only, and no alteration or transformation is made in the work. More details of this Creative Commons license are available at

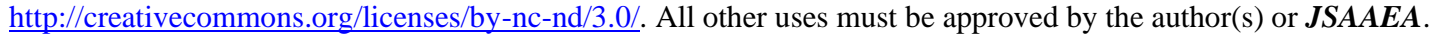

Journal of Southeast Asian American Education \& Advancement, Vol. 16. Iss. 1. (2021) ISSN: 2153-8999 
I want to hear how the Goddesses turn what is ugly into something beautiful. Make me part of that secret. Let me dance in your sun.

Both poems, the first and last, deal with Chath's ambivalence about leaving his mother and mother country as he nevertheless continues to carry them both with him in his heart and soul. The five sections of poems and sketches between these two poems record key moments in Chath's process of healing that brought him to this point.

\section{Claim Me, America}

The first section, "Claim Me, America" is comprised of 13 poems that describe two opposing forces Chath has struggled to reconcile in his new life in America. The first celebrates the promise and opportunity of his new home, while the second reminds him of the burden of survival that continues to limit his capacity to take full advantage of these opportunities. Chath's gratitude for the possibilities life in America offers is expressed in the second poem in this section, "America, my America." He lays down his heart and soul before his adoptive country asking to be taken in and permitted to experience her climate and geography and freedom. As a refugee, he takes nothing for granted:

I salute you, America, for helping my dream take flight,

Letting me be, see and become, to work and play,

Eat and sleep to life's breathlessly beautiful hills,

Mountains, valleys, above and below.

In a subsequent poem in this opening section, "In Paradise," Chath acknowledges the personal limitations that constrain him along his journey of healing in America, while anticipating the steps he knows he must take if he is to liberate himself from these constraints. While working on a farm in Massachusetts, Chath observes the birds around him:

I can't help but envy their freedom,

How lavish their colorful plumes, sky rulers,

While I farm in the sun, longing for love.

I should live other lives I haven't tried,

Travel as a vagabond, meeting singers and dancers.

Instead, I regress, fantasize, dodge truth, craft false hopes,

Give away my time, my breath, to earn half a life,

Stuck in the now, with tomorrow a last resort.

Upon turning 18, Chath pursued his quest “to live other lives [he hadn't yet] tried." (In fact, Chath's actual age is two years older than his "American age." He and his brother recorded his date of birth as 1970 instead of 1968, when applying for asylum in the Thai refugee camp, in order to give him more years to recoup his education after arriving in the United States). Upon turning 18 and becoming a legal adult, Chath took the necessary steps to become a U.S. citizen. At the same time, he changed his name from Uy Bun Thoeun, his "Cambodian name," to his "American name," 
Chath pierSath, which roughly translates as "National Temple" and also recognizes his oldest brother, Pierom, who died during the genocide. This was Chath's first decisive step at reinventing himself and defining himself in his adoptive country.

Chath boldly took the next critical step in his journey after graduating from high school in Denver. He applied to a college and pursued a degree in the world studies program at World College West in Petaluma, where he worked full-time to pay tuition and stayed with a family as a nanny in exchange for room and board. Chath took advantage of study abroad opportunities offered by the college and travelled to the former Soviet Union as the Cold War was coming to an end, taking a memorable train ride from Paris to Moscow. His horizons were expanding quickly. After graduation in 1993, Chath made his way south to San Francisco, where he "discovered his sexuality" and reveled in the city's gay life during the early 1990s. It was at this point that Chath also started to write poetry in the spirit of Walt Whitman. He recounts this seminal period in his life in "An American Sex Education":

I write to Walt Whitman to be reincarnated as my lover.

I write to Jack Kerouac to get him to come back to Lowell.

I want him to know that we have crossed paths.

I traveled his roads.

...

I am a Khmer-born American with almond-shaped eyes.

I am content, I am beautiful, I like my black hair,

My flat nose, my brown, mahogany skin,

My lips creamed by the kisses of American dawns.

My heart throbs to American lovers, close and distant, As new exotic days or nights.

In the bay of San Francisco, I discovered my sexuality.

My American men are on their way to heaven.

The poems in this first section of the book lurch back and forth between the new and old, the beckoning possibilities of the future and his deep ties to the past. As Chath took every opportunity to liberate his mind and body, he simultaneously followed the events unfolding back in Cambodia, where greed, corruption and opportunism fed by laissez faire capitalism were overrunning the country and squandering what remained of its ancient culture and beauty. In response, Chath felt a strong personal obligation to leave his new life in America and return to his mother country. In "The Loneliest Winter," he writes:

In my humid ancestral home, rice fields become house lots.

Mass graves are buried over to cover the past.

In that capital of scoundrel and dogs,

Bitches are whoring for American dollars to build

Private gilded spires, palaces and pagodas,

Where I was beaten and defeated time again and again,

Yet, I feed on old memories, scents and childhood,

Umbilical ties mocking me for betraying my roots, 
Where I feel obliged to serve.

In 1994, Chath acted on his feelings of obligation to his mother country and returned to Cambodia for the first time since escaping with his older brother and sister in 1980. The previous year, the UN had conducted national elections that effectively began the reconstruction of Cambodia's society and infrastructure in the aftermath of the genocide. Chath's return as a member of the American humanitarian organization CANDO provides the general context for the second section of poems, "I Lost My Kampuchea."

\section{Lost My Kampuchea}

The return to the exact place where the traumatic crimes of the past took place is often identified as a critical step in the process of healing for survivors. The return serves to validate the truth of the crimes, that they actually took place and were not some horrific nightmare. Bearing witness and affirming the truth of the crimes that took place is the guiding purpose of survivor literature. Delving into the poetry of witness was an important and necessary episode in Chath's process of healing as well, and he provided his personal literary testimony in his first collection of poetry, After, published in 2009.

The poems in this section of On Earth Beneath Sky, however, serve a somewhat different purpose. They describe another ongoing struggle in Chath's process of healing, as he finds his attempts to locate himself in relation to his mother country to be untenable, unstable and constantly shifting. In these poems, Chath takes a cold, hard look at what was happening in Cambodia in the 1990s and saw that it is not then and would never be the Cambodia that he knew as a child growing up before the genocide. The poems and sketches in this section describe his ongoing attempts to loosen the grip that his memories of the past continued to have on him in order to live a fuller life in the present. The second poem of the section, "I Lost You," begins:

I lost you then and now, even today, I've lost you.

Every day, not a day when I had not thought of losing you.

I think I've lost you to the future, too.

I beg and pray, but know I must lose you, the way

A snake sheds its skin, a crab goes soft for another stage of life.

This poem is followed by two sketches or short prose essays. The first describes the historical events that led to the Khmer Rouge taking power in 1975, particularly the Nixon-Kissinger illegal bombing of Cambodia. The second describes Chath's visit to the Tuol Sleng Genocide Museum, currently a popular tourist destination owned and operated by a Japanese company, that was previously the notorious Khmer Rouge torture center, S-21, where approximately 15,000 prisoners were tortured and executed and only eight survived to bear witness to the atrocities that took place there. These two sketches trace Chath's intellectual processing of the crimes and the aftermath of the genocide as he struggles to locate himself in relation to the Cambodia of today so he can "shed his skin for another stage of life."

The poem from this section that perhaps best exemplifies Chath's movement in this direction is the poem "My Father King." It is a satirical "tribute" to Norodom Sihanouk, considered the "Father of Cambodian Independence" from the French, and whose 17 years as head of state in the 1960s are looked upon nostalgically by many Cambodians as a "Golden Age." The preceding 
poem, "The Fallen Era," describes the death and funeral of Sihanouk in 2012. In contrast to "My Father King," the tone of that poem is more respectful and gives due recognition to Sihanouk's life and accomplishments, as well as his shortcomings. Following Sihanouk's death, the corrupt, authoritarian ruling party, which is deeply indebted politically and economically to the Chinese for sustaining its building boom and power base, commissioned pro forma the creation of a bronze statue of the former king that now stands in the center of the manicured gardens opposite the iconic Independence Monument, built by Sihanouk in the 1950s after gaining independence from France. In "My Father King," Chath abandons any pretense of respect and uses the statue as a metaphor for Cambodia's inexorable demise and subjugation by the Chinese.

Father King now bronze, a statue, breathing the city's smog.

In bronze suite and shoes, he's on guard, looking at his handiwork, The park full of Chinese taking photographs of themselves.

A bird on his head, a black dot at rest, drops on his bronze hair.

Then:

His back now turned to Independence, That monument once the tallest, now a miniature figure

Among skyscrapers of modernism.

King and monument together at last,

Now visited mostly by Koreans and Chinese.

The two poems about Sihanouk are followed by several scathing portraits of Cambodia's rampant corruption and greed during the economic boom that started in the early 2000s as direct foreign investment poured into the country. Poems such as "Old Familiars," "The Rent," "How to be Khmer," "Title" and the last two poems of the section, "The Life of Ochnya Yang Ly Hai" and "The Killing of an Ochnya (Excellency)," portray the Cambodian people's current obsession with titles of power, the uncharacteristic absence of humility or respect for the environment or the poor, and the cycles of violence that must inevitably follow. Although these poems were written at different times during subsequent return trips to Cambodia, their purpose in the collection is to articulate Chath's ongoing struggle to locate himself in relation to the past as he strives to move forward in his journey of healing.

\section{Mother, I'm Coming Home}

The third and middle section of the collection, "Mother, I'm Coming Home," continues this theme. Interestingly, the middle section invokes Chath's mother, who is likewise referred to in the first and last poems of the collection. Her spirit occupies the center and the periphery of the collection and Chath's existence as he lurches forward and backward in time and in and out of the spaces he tries to inhabit. As mentioned above, Chath's mother died in 1982, two years after he escaped Cambodia with his older brother and sister. She remained in Cambodia with Chath's other surviving siblings. At that time, the country was in the midst of a civil war, and the US and its allies had imposed an economic embargo on Cambodia that was occupied and controlled by its enemy, the communist Vietnamese, who had removed the Khmer Rouge from power but remained in the country until the end of the Cold War in 1989. Under these conditions, without humanitarian 
aid in the aftermath of the genocide and ongoing civil war, life in Cambodia was harsh and unforgiving for survivors who just emerged from almost four years of forced labor and starvation. Chath's mother soon lost hope and stopped eating and died as Chath's brothers did little to prevent her demise.

The section "Mother, I'm Coming Home" begins with a poem with the same title. It is an ode to her enduring spirit. Interestingly, Chath structures the poem in stanzas of three lines each with end rhymes that recall traditional Khmer verse patterns originating from the prolific literary period of the $17^{\text {th }}$ and $18^{\text {th }}$ centuries.

Sixteen years is too long.

Mother, I'm coming home

To collect your bones.

Like the previous section, "I Lost My Kampuchea," this section of poems refers to the two extended periods of time when Chath returned to live and work in Cambodia. The first was in 1994, after the UN-sponsored elections, when Chath worked for various humanitarian organizations rebuilding the country and its society after more than twenty years of war and genocide. The second was 2001, after Chath had lived and worked in Lowell with Arn Chorn Pond, a fellow survivor and activist intent on documenting and reviving traditional arts and culture. Chath returned to Cambodia and worked with Arn, as well as other artists and members of Cambodia's nascent gay community. In both sections of poems, "I Lost My Kampuchea" and "Mother, I'm Coming Home," we sense the constant tug of war between coming and going, returning and leaving that simultaneously pulls Chath in opposite directions. In this section, the poems describe Chath's final yet ultimately futile attempt to find a permanent place for himself in his mother country, this time as a purposeful and motivated activist.

Chath begins this attempt at returning by attending to the proper burial of his mother's bones. Primarily organized by Chath's older sisters in the district where they grew up, the ceremony involved digging up their mother's bones from the grave where she was initially buried in 1982 without a proper ceremony. Buddhist monks blessed the excavated bones before they were cremated, and the remains were washed several times until the water ran clear. Finally, the siblings drank the liquid in an expression of respect and gratitude to their mother's spirit. The ashes were placed in a jar and stored in a stupa at the same temple where their father's ashes were kept. (Their father died in the early 1970s fighting the Viet Cong.) In this way, the siblings both acknowledged the mother's passing from this world and internalized her spirt inside their bodies.

During this time in Cambodia, Chath both observed and participated in the sex trade that had begun with the arrival of thousands of UN peacekeepers in 1991. The peacekeepers were in Cambodia to carry out the Paris Peace Accords, which called for disarmament and national elections and the subsequent creation of a constitutional monarchy under former king and prime minister Norodom Sihanouk who had returned to Cambodia from exile. The poem that follows "Mother, I'm Coming Home," entitled "The Happiest Day," speaks to the naïve hopes for the future that most Cambodians felt following the 1993 elections.

Doves drop olive branches of the Paris Peace Accords, Everywhere white flags wave, people lay down weapons and dance.

Freedom drums in a marching band.

The King sings karaoke in his palace. 
Rain patters the city's tin, straw, and thatches absent of war's fire.

The poem continues with a more sober assessment of the current reality in the country as the hope for democracy and rule of law gave way to rampant greed and the politics of power.

The happiest day of buried sorrow

Came with new violence and political oppression,

The rise of powerful individuals above the law,

Fall of human morality and agreement. Distrust of conquest.

Peace came with brothels, a flesh market for peacekeepers

And local men who pluck young virgin breasts from poor villages

The divine king revealed to be an ordinary old boring man.

His magic doesn't work. He can't heal his nation.

Chath was in fact one of the local men who frequented the brothels. Although he was a gay man, he did not come out in Cambodia until years later when he returned again in the early 2000s and helped to organize gay rights parades. At this time in the 1990s, he was bisexual and knew the workings of the brothels first-hand. That said, Chath worked tirelessly for various humanitarian organizations to confront the HIV/AIDS epidemic decimating Cambodia, largely as a result of the sex industry created by the UN peacekeepers and international workers living in the country. One of Chath's older brothers died in 1996 of AIDS while he was still living there. In several of the poems in this section, Chath describes the continued demise of Cambodian society and culture despite the initial hopes inspired by the 1993 elections.

In "The New Cambodia," "City of Moving Flesh" and "Men are Gold, Women are Cloth: Sary's Story" Chath describes the laissez fair capitalism that had transformed his childhood memories of a sleepy Phnom Penh, where cyclo drivers slept in the shade to avoid the heat of the day, into a mad rush for instant wealth and possessions, primarily cars and SUVs, the bigger the better, such that anyone who got in your way was fair game.

Once bicycles and pedestrians, cyclos and rickshaws, now big cars, Motos and tuk-tuks taking people somewhere, home, from work,

To market, the roar of harmony or chaos, new sound of Phnom Penh,

Death-sirens, three dead a day, blood on asphalt, tar melting.

The new ethos of obsessive movement became "another form of oppression" and denial.

Do something for a change. Don't be stagnant. Don't dwell on your pain ... Stay in motion

Look ahead, don't fret about the past, stay focused on the future,

The present is now. How to be rich? How to be free?

Is just another form of oppression.

While the previous section of poems seems to articulate Chath's complicated and ambivalent realization that he must try to extricate himself from the past the way "a snake sheds its skin [to begin] another stage of life," this section of poems shows us Chath's painful estrangement from 
the Cambodia he had preserved in his imagination after seeking refuge in the US. In "Why Did I Come Back?" Chath responds to the question posed presumably by one of his older siblings.

Why did you come back?

For the same reasons you stayed.

The umbilical cord tied

To land and country.

My attempt to reconnect

With what I had known,

To fill the void.

His growing disappointment and estrangement from his relatives who were more interested in gifts of money than the love and friendship he offered them is expressed in the following poem, "The Saddest of the Sad."

I think of unannounced visits of strangers.

I address them as older brothers or sisters.

I fear men who stake claim to me as their nephew.

I am afraid to be seen wearing dollar pants \& shirt,

When all I ever wanted was a home \& country,

And a people to love and call friends.

While Chath's struggle to locate himself in relation to Cambodia has been ongoing, these two sections give us a sense of the difficulties and complexities and the continual push and pull that tears at him. When Chath left Cambodia in 1996 after his brother's death from AIDS, he sponsored his younger sister to return with him, and she currently lives in Lowell. While Chath remains in contact with his siblings, their relationship is only superficial and perfunctory. There is little direct and honest communication, since there is such little capacity or previous experience with these kinds of relationships. As mentioned above, Chath has made several trips back to Cambodia and at one time tried to live there permanently and open a business and a school. None of these projects were ever fully realized. Nonetheless, Chath continues to remain in contact with poets and artists and the gay community that he helped establish in the 2000s.

\section{Body \& Soul}

The poems in last two sections of the collection, "Body and Soul" and "Paris," describe Chath's life and lovers in the US and Paris, respectively. Here we see the poet who has "shed its skin... [to explore] another stage of life."

"Body and Soul" pays tribute to the people who have guided Chath on his journey of healing, beginning first and foremost with his literary hero, Walt Whitman. The first poem in this section, "The Body Electric," specifically credits Whitman in the title and continues with a celebration of Chath's sexual liberation. In these poems, he manages to put aside his conflicted feelings of alienation and loss articulated in the previous sections and fully immerse himself in the new identity and consciousness he has forged in his adopted America.

Electrified, I am electric, 
body and soul,

I enter the hands of time he has moved \& touched, where I felt silk \& bark of trees

against my bare back.

Chath continues his paean to Whitman in the next prose poem, "Leaves of Rice." (We should note here that rice is after all a variety of grass!)

White poet, you sang the body electric, you sang of faraway places

Where soldiers roamed.

You talked of wounds splaying

Lions and tigers,

The peeling of oppression,

The liberation of the flesh, birth and death of flowers,

What leaves of grass whispering, one masculine ear to another.

The first eight poems of this section explore the body electric from different perspectives. A common thread however is the crossing of borders, something Chath has continually had to navigate in his ongoing quest to liberate his body and soul from the traumas of the past and haunting constraints of the present. In the next poem, "A Crossroads," he refers to his days in San Francisco in the early 1990s, when he prowled the city streets.

Prowling en route, continental crossing, Borders possible to penetrate seamlessly, Freedom like stars in the sky,

Somewhere above, a name I had heard before, I repeat the breathing patterns of my lover, Heaving chest, brawn on my skin.

Chath also pays tribute in this section to his academic advisor and friend at UMass Lowell, Charles Nikitopoulos, who passed away in 2019, and to whom the book is dedicated. "Dr. Nick," as Chath called him, helped Chath in his intellectual journey to integrate his feelings of alienation and dislocation into the story of his new life in the aftermath of genocide.

Socrates- your Plato, here.

...

You taught me this much-

When leaving home with nothing, take what you can to survive,

And then root yourself in the new place

Where you can lay the foundation of a home.

What life isn't worth a second chance?

The poems and sketches in the second half of this section take a philosophical turn and plumb the spiritual depths of aging and dying and comprise the "Soul" of this section. The inspiration for these poems comes from the mother of his long-term partner, Ken, whose family owns the orchard 
in Massachusetts, where Chath has lived and worked since he returned to the United States in 2005, after his extended stays back in Cambodia and subsequently in France. Ken's mother was slowly wasting away with dementia as Ken, Ken's brothers, and Chath, tended to her.

Aging is torture, burning with loneliness.

She sits folding napkins into squares to be stuffed into her socks. ...

The graveyard where she decorated her mother's tomb

Waits for her. And sons will inherit the ritual of remembrance.

Other poems in part of the section explore metaphysical ideas. "Groundhog Day" and "Out the Window" exemplify this mode of Chath's intellectual border crossing, made possible by his determination to pursue his journey wherever it leads, dragging the burden of survival along with him if necessary. In "Groundhog Day," Chath's cosmic imagination takes flight.

I wish to enter the sky through your corridors beneath the earth.

I think you know the secrets to shorten distances

Between earth and the universe

$\ldots$

Travel through wormholes

Into the arms of other galactic inhabitants.

Burrow through salted quartz of mathematical calculations

...

You can decode the passage of time.

The poems that end this section, "The Longing Dagger," "The Man of Class," and "In Every Life of a French Man," which return to the theme of love, longing, separation and alienation, provide a transition to the final section of the collection, "Paris," which refers to Chath's return to France to be at the side of a former lover, whom he knew in Cambodia and was dying of AIDS.

\section{Paris}

In terms of their organization and placement in the collection, the last section of poems and sketches draws our attention to the symmetry of the collection's overall design. In the same way that Cambodia's most famous stone temple Angkor Wat was ingeniously constructed as a cosmological model of the Hindu universe, On Earth Beneath Sky is carefully organized to draw connections between different times and places in Chath's journey. We have already identified Chath's mother as the book's center and periphery. Similarly, it is part of the book's careful design that the final section begins with the poem "An Escape Route" that mirrors the first poem of the first section "Un Réfugié." Both poems deal with the recurring theme of dislocation, alienation and flight that is at the core of the survivor's experience and Chath's own journey to healing. The first poem of the collection describes Chath's departure from the refugee camps in Thailand and the Philippines en route to the United States, where Chath, along with his brother and sister, has been accepted for asylum. 
My brother spoke French, Un Réfugié.

He carried the IOM bag with our tags.

Refugees across borders,

From camp to Bangkok, on a plane to Manila.

Refugee route.

The title of the first poem of the final section entitled "An Escape Route" draws a straight line to the first poem of the first section, "Un Réfugié," just as the bas-relief panels in the third gallery that surrounds the Angkor Wat temple are purposefully positioned north to south and east to west to connect key figures in Hindu literature and mythology that relate to the temple's builder Suryavarman. Here, the French title of "Un Réfugie" connects to the poet's "escape" to France in "An Escape Route."

My next escape will be the south of France, Country of parfum and lavender, Into the arms of a dying friend, Another winter without a New England Christmas.

In the first poem, Chath is literally escaping from Cambodia to the United States. In the second poem, Chath is figuratively "escaping" from the United States to France to be at the bedside of his dying former lover, whom he met in Cambodia. Written in America before his "escape" to France, Chath contemplates how far he has come and yet how little some things have changed.

No matter how American I've become, Cambodia's forever my shadow.

Alone with an iced coffee, I inked out a poem

About farming to evade another nightmare.

The tone of the eight poems in this final section is contemplative. While the first four deal explicitly with the death of his bedridden former lover, they also refer figuratively to his own past lives and deaths in Cambodia and America as he has repeatedly invented and reinvented himself in his pursuit of healing and renewal. In the next poem "The Church Bell," he writes:

I hear the sound of the oncoming train of my past, My breath in and out of his timeline, far from his celebrations,

His body of joy, his lips making notes while he plays the piano.

More and more distant and inaudible, my breath in shadows,

Running from the past, drifting, a loner aiming for a dead star.

The last four poems and sketches of this final section turn from the loss of a loved one with its connections to the loss of his mother and his homeland, to the survivor's ongoing quest and longing for life and love as he wanders the streets of Paris lost and alone, feeling alienated from the world and people around him. In "Parisian Streets," he writes:

Je suis perdu. A wanderer, full of angst, as private and internal as a soliloquy.... as I wander, I look without knowing what I am looking for, but I look and look, 
until my eyes are strained, and my head anxious from too many connecting nerves and electrodes trying to translate what I see into three different languages, with my maternal one incapable of naming even the concept of a museum or a cobblestone street, full of people drinking coffee in tiny cups outside in January.

The last two items in the collection, a sketch and a poem, respectively, leave us with Chath continuing to move forward toward love and renewal, despite or because of the loneliness and dislocation that he feels. In the sketch "The Metro," Chath takes us through the French underground "racing for love, and for life- anything to fill the emptiness and loneliness inside." The train stopping and starting with people boarding and departing offer new possibilities for human connection, love or a night of anonymous sex.

The train in its climax of speed and from speed to brake, embracing the track ever so tightly, ever so urgently ... neck to neck with someone they wish to love or to hate, what pleasure the body will give for a night of anonymous sex. Tenderness comes when the train opens to fresh air, passengers in and out like a trap to and from places and destinations ... hoping for the one I had lost in the past, if only he would reappear, I would follow him to the end of the earth. I would be willing to give him all my breaths in his mother tongue. Je veux être avec toi.

Above ground again (figuratively and literally), the river Seine and the Parisian streets become a metaphor for his body and internal life.

Out by the river, without direct sunlight, it's dark as the blood in my body. The river flows as do rivers in my body, full of tunnels and train tracks of veins the size of a single strand of hair, from which organs make lakes and oceans. ... If only I could travel in my own lit veins, what would I see? Is it the same landscape as this city?

The sketch ends with the telling response: "He shines light to see what's inside his own darkness." We know that Chath will continue to struggle and move forward through the darkness of surviving in search of healing and renewal and human contact.

\section{Afterword}

Chath pierSath refuses to be confined by boundaries, whether the physical borders of nations or the conceptual borders of social categories. He started crossing borders when he fled Cambodia in 1980 with his older brother Thol, and he has not stopped. As the title of this collection of poems suggests, his "boundaries" are the earth and the sky, but that is a convenient metaphor based on the lyrics of a popular song from Cambodia's so-called "Golden Age" from the 1960s during the Sihanouk Era. Chath's actual horizons, if he has any at all, go much further, from the cellular level of the body's veins and organs to the farthest planets and stars in the cosmos; and this expansive perspective is reflected in his language. In turns, his images are now firmly grounded in the living things of the earth; the trees and plants and the changing seasons; the winter snows and spring rains that collect into rivers and flow to the sea; now in the body's currents of blood that pool and circulate in its organs and limbs; now by the infinite stars and planets orbiting unknown solar 
systems. And for Chath, these realms are not separate, nor can they be contained by arbitrary names or boundaries. They are interconnected, indefinite and interdependent. Chath sees the earth as an astronaut would see it from space, swirling masses of land and water, borderless and nameless.

\section{About the Author}

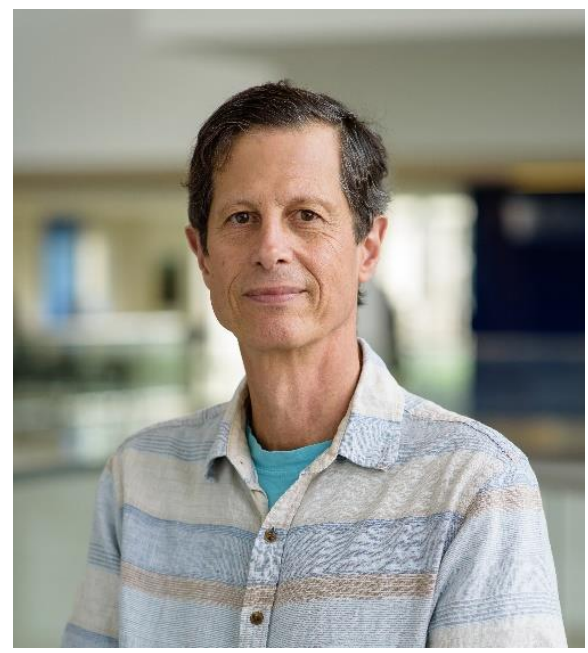

George Chigas is an Associate Teaching Professor in Cambodian Studies at the University of Massachusetts Lowell, where he teaches courses in Cambodian literature and cultural history. He is the author of Tum Teav: A Translation and Literary Analysis of a Cambodian Classic. 


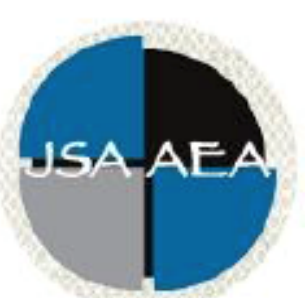

Vol.16 Iss.1 (2021)

\section{Journal of Southeast Asian American Education and Advancement}

\author{
Editor \\ Dr. Wayne E. Wright \\ Purdue University \\ Associate Editors \\ Dr. Chhany Sak-Humphry \\ University of Hawaii at Manoa \\ Dr. Phitsamay Sychitkokhong Uy \\ University of Massachusetts, Lowell \\ Book Review Editor \\ Dr. Vichet Chhuon \\ University of Minnesota \\ Creative Works Editor \\ Bryan Thao Worra \\ Lao Assistance Center \\ Journal Manager \\ Chen Li \\ Jeffrey Sovan Wright \\ Purdue University
}

\title{
Editorial Review Board
}

\author{
Dr. Steve Arounsack \\ California State University, Stanislaus \\ Dr. Sovicheth Boun \\ Salem State University \\ Dr. Virak Chan \\ Purdue University \\ Dr. Loan Dao \\ University of Massachusetts Boston
}

\author{
Dr. Carl L. Bankston III \\ Tulane University \\ Dr. Phala Chea \\ Lowell Public Schools \\ Dr. George Chigas \\ University of Massachusetts, Lowell \\ Dr. Hien Duc Do \\ San Jose State University
}


Dr. Linh Dang

KIPP DC Headquarters

Dr. Sophal Ear

Occidental College

Dr. Vincent K. Her

University of Wisconsin, Eau Claire

Dr. Nancy H. Hornberger

University of Pennsylvania

Dr. Peter Tan Keo

New York University

Dr. Yvonne Kwan

San Jose State University

Dr. Ravy Lao

California State University, Los Angeles

Dr. Stacey Lee

University of Wisconsin, Madison

Dr. Jacqueline Mac

Northern Illinois University

Dr. Bic Ngo

University of Minnesota

Dr. Leakhena Nou

California State University, Long Beach

Dr. Mark Pfeifer

SUNY Institute of Technology

Dr. Loan T. Phan

University of New Hampshire

Dr. Karen Quintiliani

California State University, Long Beach

Dr. Angela Reyes

Hunter College

The City University of New York

Dr. Fay Shin

California State University, Long Beach

Dr. Christine Su

College of San Mateo

Dr. Alisia Tran

Arizona State University

Dr. Khatharya Um

University of California, Berkeley

Dr. Kim Tran

University of California, Los Angeles,

Glendale Community College

Dr. Molly Wiebe

The University of Texas at Austin
Dr. Changming Duan

University of Missouri-Kansas City

Dr. Sothy Eng

Lehigh University

Dr. Jeremy Hein

University of Wisconsin, Eau Claire

Dr. Peter Nien-Chu Kiang

University of Massachusetts, Boston

Dr. Kevin K. Kumashiro

University of Illinois, Chicago

Dr. Ha Lam

Independent Scholar

Dr. Jonathan H. X. Lee

San Francisco State University

Dr. Monirith Ly

Royal University of Phnom Penh

Dr. Sue Needham

California State University, Dominguez Hills

Dr. Max Niedzwiecki

Daylight Consulting Group

Dr. Clara Park

California State University, Northridge

Dr. Giang Pham

University of Massachusetts Amherst

Dr. Malaphone Phommasa

University of California Santa Barbara

Dr. Kalyani Rai

University of Wisconsin-Milwaukee

Dr. Cathy J. Schlund-Vials

University of Connecticut, Storrs

Dr. Nancy J. Smith-Hefner

Boston University

Dr. Yer J. Thao

Portland State University

Dr. Monica M. Trieu

Purdue University

Dr. Silvy Un

Saint Paul Public Schools

Dr. Linda Trinh Vo

University of California, Irvine

Dr. Varaxy Yi Borromeo

California State University, Fresno

Dr. Yang Sao Xiong

The University of Wisconsin-Madison

\section{Dr. Zha Blong Xiong}

University of Minnesota 


\section{Doctoral Student Editorial Review Board}

Diana Chandara
University of Minnesota-Twin Cities
Bao Diep
University of Minnesota-Twin Cities
Vanessa Sovanika Na
University of California San Diego
Khoi Nguyen
George Mason University
Hoa Nha Nguyen
Boston College
Linda Marie Pheng
University of Wisconsin-Madison
Latana Thaviseth
University of California Los Angeles
Melissa Vang
San Diego State University

Diana Chandara

Bao Diep

rsity of Minnesota-Twin Cities

y of California San Diego

rge Mason University

Hoa Nha Nguyen

Boston College

rsity of Wisconsin-Madison

ity of California Los Angeles

San Diego State University

\author{
Kassandra Chhay \\ University of Minnesota-Twin Cities \\ Annie BichLoan Duong \\ San Joaquin County Office of Education \\ Nielson Hul \\ Cornell University \\ Dung Minh Mao \\ University of Minnesota-Twin Cities \\ Thien-Huong Ninh \\ University of Southern California \\ Krissyvan Truong \\ Claremont Graduate University \\ Mai Vang \\ University of Massachusetts Boston \\ Thong Vang \\ University of Minnesota-Twin Cities
}

Soua Xiong

San Diego State University

Claremont Graduate University 